Historic, Archive Document

Do not assume content reflects current scientific knowledge, policies, or practices. 
, 


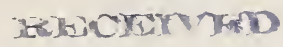 \\ 2. JUN 181927 \\ GLADIOLUS BULBS}

\section{DAHLIA TUBERS}

SEASON 1927

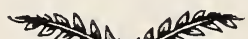

22140

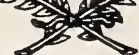

CUT FLOWERS IN SEASON

of

NARCISSUS, TULIPS, PEONY, IRIS,

FYRETHRUM, SHASTA DAISY,

GAILARDIA, GLADIOLUS,

DAHLIA and OTHERS

WYATT FLOWER GARDENS AUBURN, INDIANA

Member of A. G. S. Society 


\section{Kunderd Ruffled Gladiolus}

103 Ardmore.-Tall lavender pink, deeper throat blotches, finely ruffled.

Each $10 \mathrm{c}$

106 Crescent Queen.-Very large, dark wine red. A beautiful variety of this color. Each $5 c$

107 E. J. Shaylor.-Tall, very strong plant and large blooms. Deep, pure rose pink.

Eack 10c

114 Orange Glory.-Grand orange colored, with beautiful lighter throat.

Each $15 \mathrm{c}$

119 Purple Glory.-Deepest velvety maroon red, with almost black blotch, like burned into petals.

Each $35 c$

120 Red, White and Gold.-Upper portion of bloom, pure white. Lower petals entirely of a rich lemon yellow clear to the edge, with a beautiful blotch of richest red on each.

Each $10 \mathrm{c}$

121 Rose Glory.-Purest rose-pink color. Deeper in throat.

Each $25 c$

125 White Belle.-Tall, strong. Delicate blush white, deeper at edges. Beautiful throat.

Each $10 \mathrm{c}$

126 White Glory.-A gorgeous pure white with beautiful iris-blue throat.

Each $10 \mathrm{c}$

128 Youell's Favorite.-Large flower and plant. Striking rosy lavender pink. Conspicuous and fine.

Each 15c

\section{Kunderd's Plain Petaled Gladiolus}

201 Al Shira._-Large, very dark wine red, with almost black throat.

Each $10 \mathrm{c}$

203 Americanus.-White, flushed delicate pink. Fine barred and penciled throat. Each 5c

207 Cairo.-White lines extending from base of darker red throat.

Each $5 \mathrm{c}$

208 Challenger.-Large, dark rich velvety red, solid color.

Each $10 \mathrm{c}$

210 Chicago White.-Very early white, choice florist's variety

Each 5c

212 Corunna.-Large flower with wide-spreading petals. Has a very large, almost coal-black throat, bordered white.

Each 20?

214 Dixie.-One of the deepest and richest almost black red.

Each 5c

219 Floral Treasure.-Tall lavender pink. A beautiful orchid color.

Each 10c

224 Ida Van.-A beautiful flaming orange-pink. Very rich and brilliant color.

Each 5c 
235 Mrs. Frank Pendleton.-Bright rose-pink on a pure white ground. A giant blotch of richest carmine red on lower petals. No grander variety in existence.

Each $10 \mathrm{c}$

239 Pella.-Very early, beautiful rose pink. Extra fine.

Each $10 \mathrm{c}$

244 Red Wing.-Fine red. Good height, medium sized flowers, several open at a time. Beautifully blotched throat.

Each $4 \mathrm{c}$

245 Searlet Princeps.-Six or more massive bright scarlet blooms open at a time. Throat a little darker.

Each 25c

246 Sentinel.-Large pure rose pink with elegantly white-penciled throat.

Each $10 \mathrm{c}$

249 Unusual.-A fine aniline red, lower petals deeper. Beautifully striped and veined white.

Each 20c

256 White Orchid.-A very large and well opened white with dark red throat. Tall and showy.

Each $15 \mathrm{c}$

273 Byron L. Smith.-A very delicate lavender pink on white ground. Lighter in throat.

Each 25c

\section{Kunderd's Primulinus Hybrids}

301 Albia.-Tall, many open. Richest rose pink, lighter throat.

Each 5c

303 Anamosa.-Extra tall, finest orange salmon; golden throat. Very large, many open. Very beautiful. Each 5c

304 Angola.-Fine salmon pink. Each 5c

307 Bobolink. - Tall slender spike. Orange tinted yellow with entire lower petals of richest deep daffodil-yellow; deeper in throat.

Each $10 \mathrm{c}$

309 Cassandra.- - Soft salmon buff deeper on outer border.

Each $5 c$

310 Cutie.-Tall slender graceful plant. Small rich yellow blooms oddly notched or crimped, neat and dainty.

Each $3 \mathrm{c}$

311 Doris.-Tall, slender, graceful plant. Creamy white blossoms with deep canary colored throat finely blended.

Each $5 \mathrm{c}$

313 Fire Fly.-Extra bright, richest deep scarlet. Pure rich self-color.

Each $5 c$

319 Redano.-Soft sulphur. Often all petals penciled pink.

Each $5 \mathrm{c}$

322 Species (Primulinus).- This is not, strictly speaking, a variety, but a species which is native in South Africa, and is the best pure all-yellow of the species.

Each $3 c$ 
323 Svea.-A dainty salmon pink with lower petals of deep canary yellow blended to pink at border.

Each $10 \mathrm{c}$

326 Tupelo.-Tall, large blooms, many open. Deepest canary yellow. Fine throat lines.

Each 5c

327 Twinkles.-Tall slender graceful plant. Flowers of finest shade of salmon-rose. Throat of lighter shade of the same color blushed over a dainty buff ground. Each 20c

329 Zenobia.-Showy orange red; lower petals lighter with orange red throat. Each 5c

\section{Kunderd's Ruffled Primulinus Hybrids}

402 Boquet.-Of a light yellow color; lower petals deeper and beautifully penciled pink.

Each 5c

403 Butterfly.-Large pale yellow ruffled flowers. Each 5 c

404 Gold Drop.-An extra large, pure deep yellow, with beautiful red lines on lower petals.

Each 10e

406 Golden Gate.-An extra tall, graceful flower. Earge showy yellow; finely ruffled. Each 5:

408 Sedan.-Rich yellow with crimson bar on lower petals.

Each 5e

409 Sirus.-Large dark salmon rich throat; finely ruffled.

Each $5 \mathrm{c}$

000 Kundered Glory Mixture.-An extraordinary mixture composed of all choice varieties.

Dozen $\$ 1.00$

0000 Primulinus Mixture.-A mixture of the primulinus types embracing many shades and colors.

Dozen $\$ 0.50$

\section{Additional Varieties}

2 America (Banning).-Beautiful soft lavender pink.

Each $5 \mathrm{c}$

3 Panama (Banning)._-Bright pink almost self color.

Each $5 c$

4 Niagara (Banning).-Delicate cream blending to a canary yellow, throat splashed with carmine.

Each $10 \mathrm{c}$

6 Princeps (VanFleet).--Immense flowers of rich crimson-scarlet with white throat; blotched on lower petals. Each 5c

9 Barron J. Hulot (Lemoine).-A beautiful rich indigo blue. One of the finest blue gladiolus.

Each 10c 
15 Schwaben (Pfitzer).--Pure canary yellow, shading to a soft sulphur yellow. Each $10 \mathrm{c}$

16 Peace (Groff).--Large white with a delicate (lilac) feathering on lower petal. Each 5c

18 Louise (Wright).-Beautiful shade of bright lavender with darker center; large flowers.

Each 10 ?

22 Pink Biauty (Von Thol).-Deep pink with maroon blotches. $\quad$ Each $5 \mathrm{c}$

23 Yellow Bird.-A good yellow with a dash of tyran-rose in throat.

Each 5c

24 Arizona.-Beautiful light pink with darker throat. Each $10 \mathrm{c}$

26 Gretchen Zang (Austin).--Tall soft shade of pink blending into scarlet on lower petals.

Each $5 c$

36 Roem Von Kennemerland (Welthuys).-Deep rose pink with yellowish throat. Each 10c

37 Chateau Thierry (Vos).-Orange cerise with yellow bordered red blotch. Each 10c

The above varieties are offered subject to prior sale; guaranteed true to name but only to the extent that we will replace free of charge any bulbs found to be otherwise.

Prices: Are for bulbs 1 and $1 / 4$ inches and up and include free delivery on amounts of $\$ 1.00$ or more; for less than $\$ 1.00$, add $10 \%$.

One.dozen bulbs at ten times the price of each. orders.

Deposit: One-fourth cash with all C. O. D.

If any varieties are sold out we reserve the right to substitute another variety of equal or greater value, unless instructed not to do so.

We grow over one hundred varieties not included in this list. Our stock of the others is too limited to catalog, but could spare a few of any. Should you not find what you want listed here, write us.

We cordially invite you to visit our gardens cluring the blooming season and enjoy their wonclerful beauty with us. 


\section{DAHLIAS}

115 Snowclad (Pompon).-Sturdy plant with pure white blossoms.

Each 25c

117 Paul Michael (Decorative).-An immense flower of bright apricot and bronze shadings. Belongs in the largest dahlia class.

Each $\$ 1.50$

118 La Favorita (Hybrid Cactus).-A beautiful, deep orange shade, each bloom carried on a strong stem. Shows a full center even late in the season.

Each 75 c

119 Millionaire (Decorative).-A giant lavender shading to white at center. Dwarf grower. One of the largest dahlias in existence.

Each $\$ 1.00$

127 A. D. Livonia (Show).-Medium size, Shell Pink, very fine cutflower.

Each 25c

\section{UNNAMED VARIETIES}

2 Varigated

Each 25c

4 Rich Dark Red Each 25e

5 Light Pink Each 102

7 Dark Purple Each $25 \mathrm{c}$

11 Light Purple Each 20c

22 Black red center shading to violet red

Each 25c

The past year the dahlia had a hard fight for existence. Their sturdy growth was handicapped by the excessive rains. In our effort to give them a good location we made an error and as a result the continued rainy season caused a loss of a large part of our stock and the complete loss of some varieties. Therefore we only list a few of the varieties which were fortunate enough in location to withstand the water and come through with a good tuber growth.

Dahlia tubers will not be delivered until planting time.

Terms same as Gladiolus.

Subscribe to "The Flower Grower" Calcium, New York. A first-class floral magazine. Monthly. Price $\$ 2.00$ per year. 